\title{
C-36 CAMPANO-LUCANO APENNINE SECTOR - ALLOCHTONOUS SHEETS STRUCTURAL SETTING
}

R. PETTINELLI

Eni SpA Agip Division, Via Emalia 1, 20097 San Donato Milanese, Italy

\section{Abstract}

Key words: Campano-Lucano Arc, M. Alpi, M. Raparo, breaching thrusts, mio-pliocene tectonic phases

In the Campano-Lucano Apennine southernmost sector, a structural and stratigraphic revision study project of the tectonic nappes, achieved by defining some reference allochtonous sections whose both structural setting and cinematic evolution models, were reconstructed (Fig. 1).

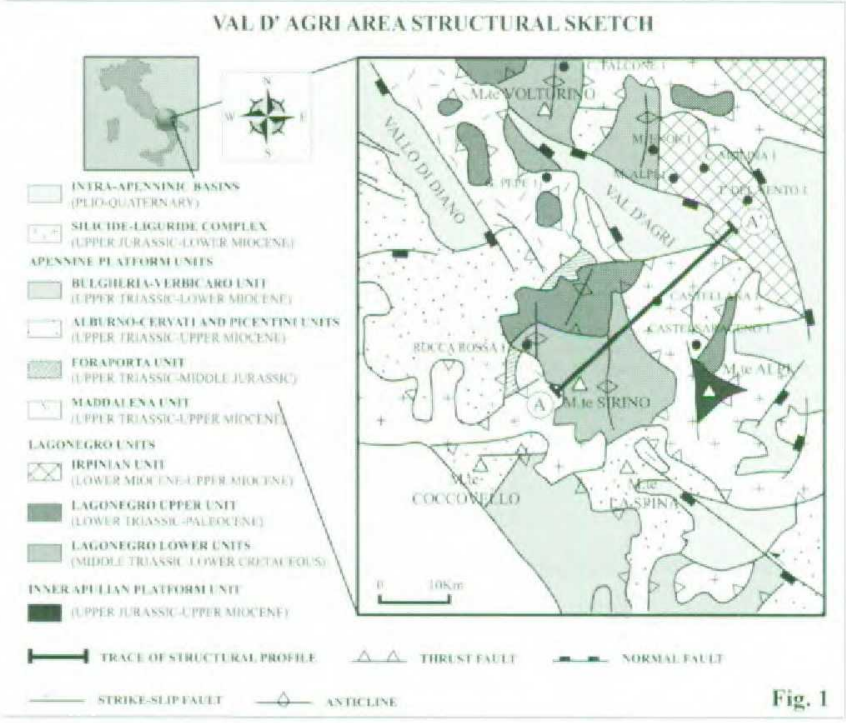

The study, aimed at a three-dimensional outline of the Inner Apulian Platform overburden setting, in the Val d'Agri and surrounding areas, is part of a greater depth modelling project of the Cerro Falcone-M. Alpi oil field carbonate reservoir. A multidisciplinary

structural-stratigraphic approach was then applied, integrated by a detailed seismic interpretation of the whole 2D grid available in the study area.

The remarkable data set, as derived from the several exploratory and development wells drilled during the last ten years, was the basic reference for the modelling: a finely tuned reconstruction of the tectonic units' reciprocal geometric relationships was allowed.

The integrated surface geology data (stratigraphic sections and detail field surveys), mainly relevant to other unpublished AGIP studies, achieved the thrusted belt paleogeographic relationships interpretation of each tectonic unit as well as the orogenetic key-events timing.

\section{Allochtonous Units}

Some allochtonous sections, identifying the overall structural setting, were described in the study area; they originated by a complex mio-pliocenic tectonic evolution, significantly affected by the early structuring phases of the Inner Apulian Platform (IAP, Mostardini \& Merlini, 1986). 
These sections, schematically shown in Fig. 2, are respectively referred to the M. Enoc, M. Alpi-Costa Molina, Tempa Rossa-Perticara, Castellana-Castelsaraceno, M. Raparo and M. Alpi zones.

The main detachments took respectively place at the base of: the "Sicilide" (Auctt.) and "Liguride" (Ogniben, 1969) units, the "Campano-Lucana Platform" (CLP), the "Lagonegro Units" (LU) and at the contact of the last with the cenozoic "Irpinian Units" (Cocco et alii, 1972). Minor detachments commonly occur at the stratigraphic contact between the M. Facito and Calcari con Selce fms. as well as between the Flysch Rosso and Numidian Flysch Fms.

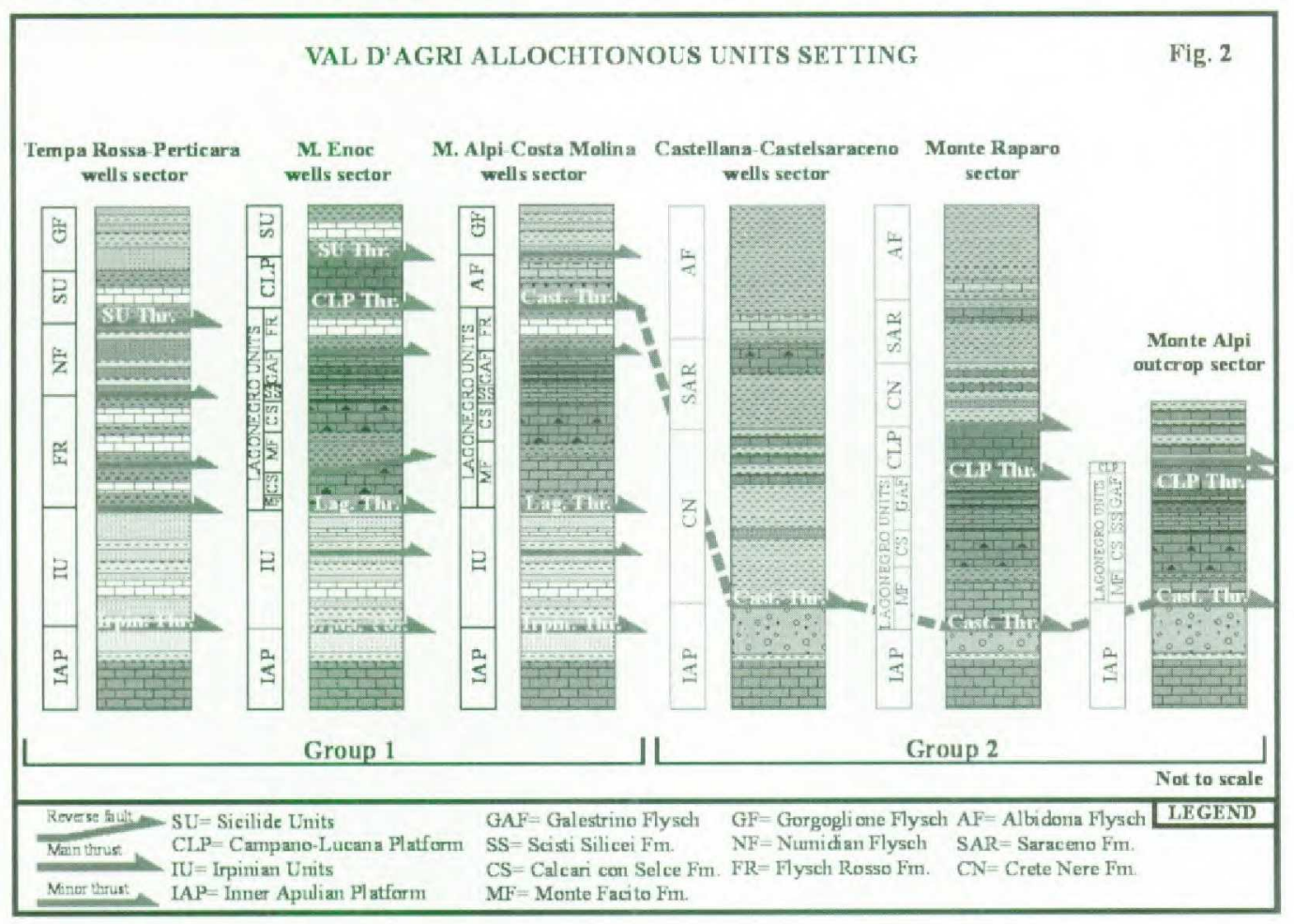

The allochtonous type sections were subdivided into two groups; the first characterised by miocene silicoclastic units (Irpinian Units) directly carried over the apulian domain "foredeep" polygenic conglomerate deposits of inferred Late Messinian age (Sgrosso, 1988).

Some regional scale overthrusts, with relevant shortening up to tenths of kilometres, have been identified within these sequences, from top to bottom, namely: Sicilide Units Thrust, Campano-Lucana Platform Thrust, Lagonegro II Thrust, Lagonegro Thrust, Irpinian Thrust; other lower rank thrusts (Castellana Thrust, M. Torrette Thrust), settled as breaching thrusts (Butler, 1987), are deeply affecting the allochtonous sheets tectonic framework.

The evolutionary scheme to explain the first group tectonic setting can be summarised as follows: Sicilide Units (Auctt.) post-Burdigalian thrusting over the Campano-Lucana Platform which in turn, during Early Miocene time (upon Alli 1 well results), thrusts the Upper Lagonegro Unit (M. Arioso Pescatore et alii, 1988; Lagonegro II pro parte, Scandone, 1972); Irpinian Units thrusting, as Inner Apulian Platform first tectonic cover, during Early Pliocene times (above the $G$. puncticulata $+G$. Margaritae or the $G$. puncticulata zones, respectively within the Val d'Agri and the Perticara-Tempa Rossa sectors) and, eventually, the entire allochtonous pile (cutting the Irpinian Thrust) carried above the Irpinian Units (Lagonegro Thrust). In the M. Alpi-Costa Molina wells area, where CLP is absent, the Castellana Thrust, which here affects only the mesoautochton portion of the liguride paleogene accretionary prism, puts the Albidona Flysch directly above the Lagonegro Units.

The second sections' group may be related to later movements (breaching thrusts), cutting through the miocene tectonic pile (whose original setting was almost similar to that of the first group), which brought Lagonegro and/or Liguride Units to directly overlay the Inner Apulian Platform (Pettinelli \& Rea, 1998).

Fig. 3 shows the Castellana-M. Raparo-M. Alpi sector cinematic framework, from Early Miocene through Late Messinian-Zanclean times. Each allochtonous setting that characterise 
the group 2 might be explained considering three pre-existing different belts, almost perpendicular to the Castellana Thrust.

A Castellana-Castelsaraceno well-like tectonic setting, characterised by the Liguride Units directly thrusting above the Inner Apulian Platform, might be referred to an upthrown block innermost position, where inner units (as Liguride Units) may thrust straightway over a still undeformed fore-land. M. Raparo like situations, where the CLP overthrusts a Lagonegro section which, in turn, would result directly overlying the IAP (unpublished data from an AGIP magnetotelluric survey), might be referred to the central part of the overthrusted block.

CASTELLANA - M. ALPI SECTOR STRUCTURAL EVOLUTION

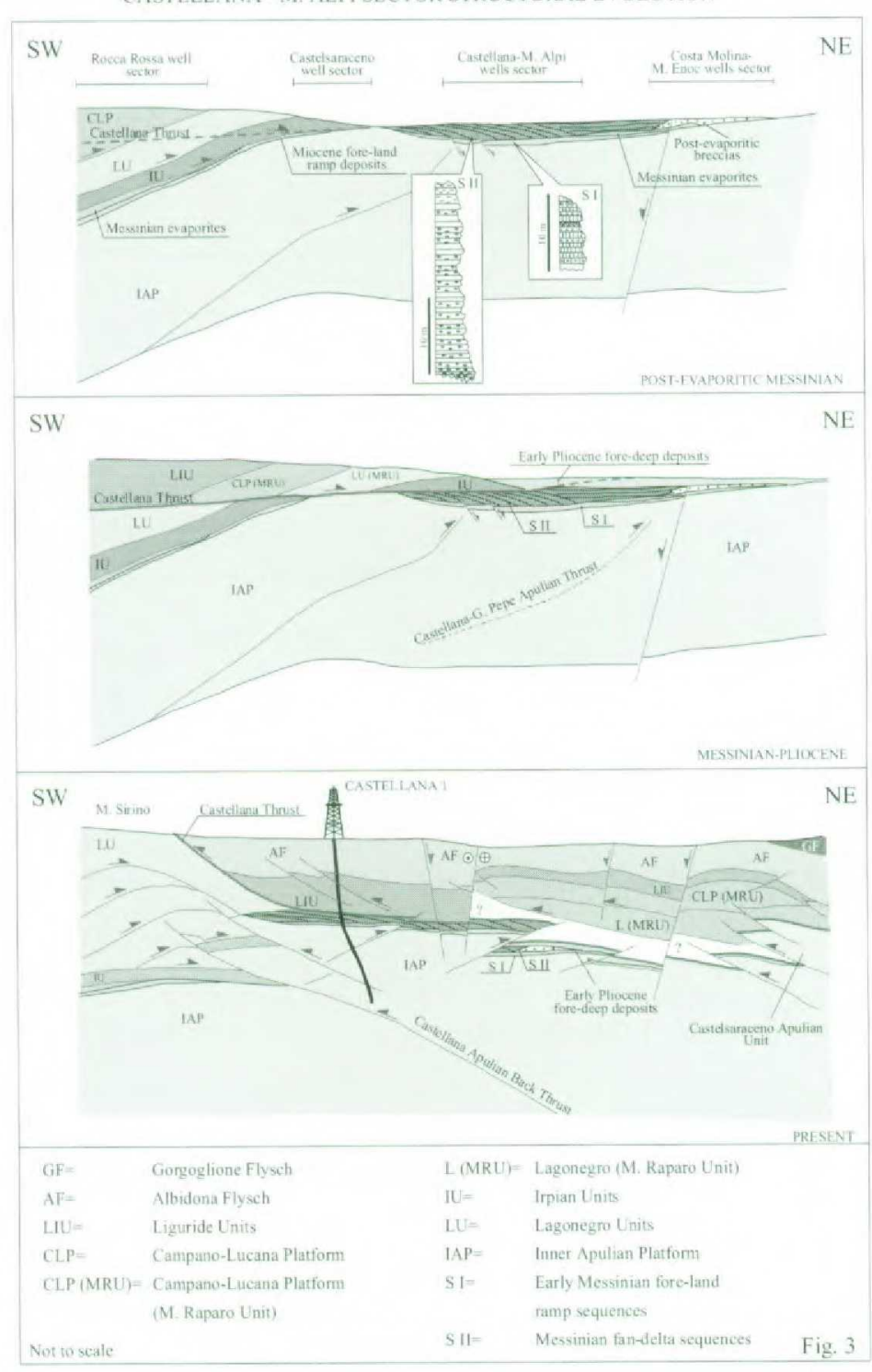

The maximum tectonic thinning phenomena affecting the LU, overlain by small CLP sheets, and transported right above the Latronico M. Alpi Apulian Unit (Sgrosso, 1988; Van Dijk et alii, in press), can be related to the Castellana Thrust front sector, assuming a thin skinned cut of the miocenic duplex structure (Fig. 3).

Similar phenomena have been detected in the northern part of the Val d'Agri, where anomalous juxtapositions with respect to the proposed tectonic framework were monitored between CLP and LU. In this area, particularly, the CLP cuts down section both the M. Arioso and the underlying M. Volturino LU: all this leads hypothesizing a sole thrust rejuvenation by late compressive movements ( $\mathrm{M}$. Torrette Thrust).

The breaching thrusts development during the miocenic compression conclusive phases therefore appears as a significant event in the Southern Apennine chain building, whose 
relevant shortenings, before being totally transferred to the IAP, during this phase develop as low angle slivering fractures, apparently independent from the allochtonous pile setting.

By this time, we might hypothesize a progressive shear zones transfer from deeper to shallower detachment levels, which locally, as in the studied sectors, can easily fragment remarkable portions of the allochtonous pile, allowing up to $10-20 \mathrm{~km}$ shortening.

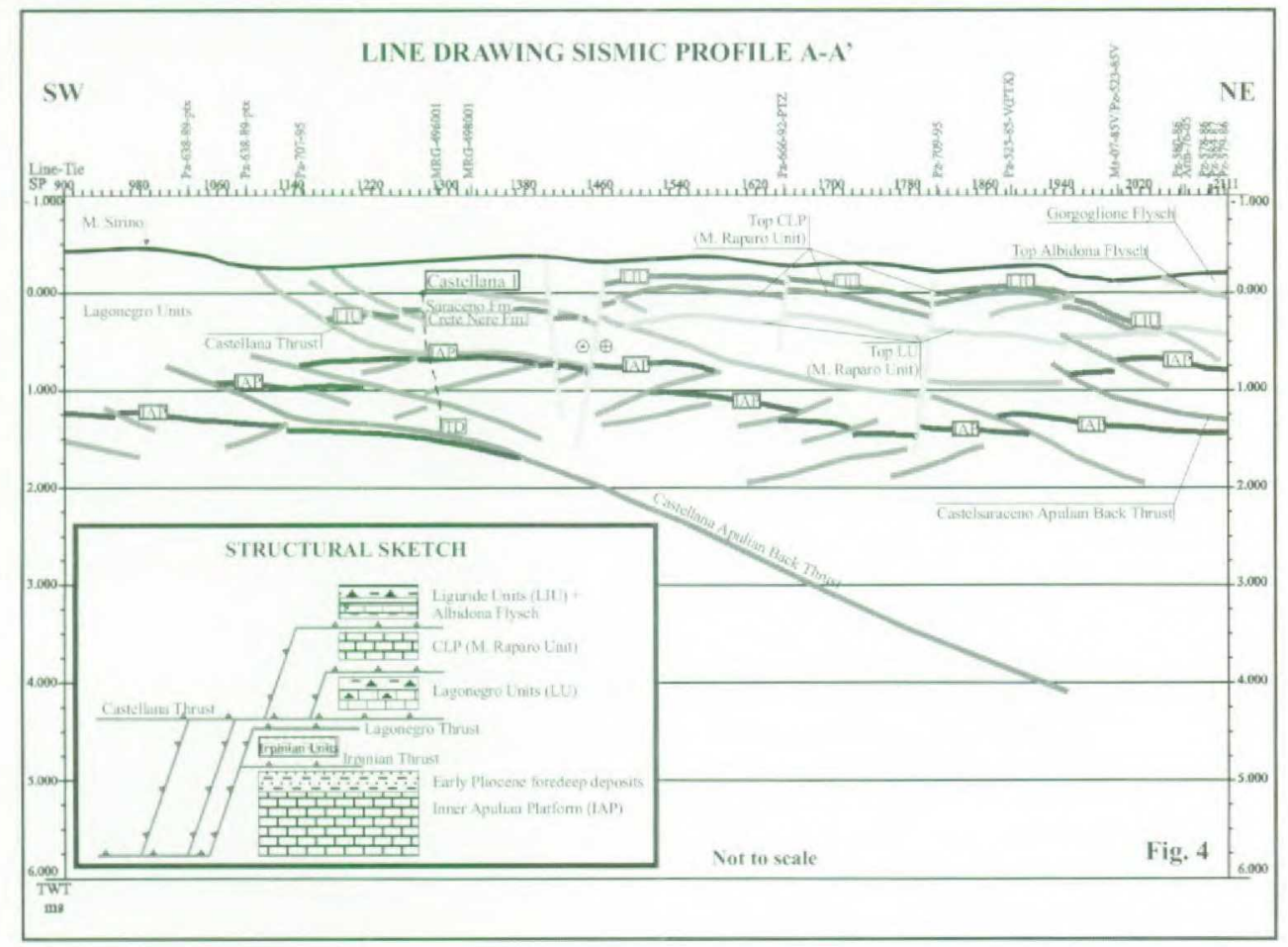

The phenomenon terminates when the Apennine Arch shortening starts affecting the IAP, from Late Miocene time: this phase will culminate in the Tempa Rossa crustal slivering by oblique compression, active at least until the early Pleistocene (Menardi \& Rea, in press).

\section{REFERENCES}

Butler R. W., 1987 - Thrust sequences - Journal of the Geological Society of London, 144: 619-634.

Cocco E., Ortolani F., Pescatore T., Russo M., Sgrosso I., Torre M., 1972 - Les faciès sedimentaires du Bassin Irpinien (Italie Méridionale) - Atti Accad. Pontoniana, 21: 1-13.

Menardi Noguera A., Rea G., in press - The Campanian-Lucanian arc deep structure (Southern Apennines, Italy) - Tectonophysics.

Mostardini F., Merlini S., 1986 - Appennino Centro-Meridionale: sezioni geologiche e proposta di modello strutturale - Mem. Soc. Geol, It., 35: 177-202.

Ogniben L., 1969 - Schema introduttivo alla geologia del confine Calabro Lucano - Mem. Soc. Geol. It., 8: 453 763.

Pescatore T., Renda P., Tramutoli M., 1988 - Rapporti tra le unità lagonegresi e le unità sicilidi nella media valle del Basento, Lucania (Appennino Meridionale) - Mem. Soc. Geol. Ital., 41: 353-361.

Pettinelli R., Rea G., 1998 - Sequenze di sovrascorrimenti nell'Appennino Campano-Lucano - Abstract Congresso della Società Geologica Italiana, Palermo 21-23 settembre 1998, Vol. B: 667-668.

Scandone P., 1972 - Studi di geologia lucana: carta dei terreni della serie calcareo-silico-marnosa e note illustrative - Boll. Soc. Natur: Napoli, 81: 225-300.

Sgrosso I., 1988 - Nuovi dati biostratigrafici sul Miocene del M. Alpi (Lucania) e conseguenti ipotesi paleogeografiche - Mem. Soc. Geol. Ital., 41 (1992): 343-351.

Van Dijk J. P., Bello M., Toscano C., Bersani A., Nardon S., in press - Tectonic model and 3D fracture network study of the Monte Alpi carbonates (Southern Italy) - Tectonophysics. 